\title{
The Development of Self-Help Book as A Media in Career Planning for Undergraduate Student in Indonesia
}

\author{
Dzinnun Hadi ${ }^{1}$ \\ ${ }^{1}$ Institut Agama Islam Negeri (IAIN) Tulungagung \\ 1dzinnunhadi@gmail.com
}

\begin{abstract}
This research aims to develop a self-help book to inform the students about the steps in career planning. This research uses The Research and Development method developed by Borg and Gall. The research was classified as a small scale $\mathrm{R} \& \mathrm{D}$ research because the research was carried out using only a few steps. The steps are research and collect information, planning, development of the initial product format, initial product validation, and product revisions. In the validation step the product is assessed by three expert validators, the media expert validator, the material expert validator, and also assessed by the user's validator, the students in SMAN 1 Tulungagung. This research produces a self-help book entitled "Kamu Mau Jadi Apa?". The contents of the self-help book in career planning are Know Yourself: Who You Are; Find Out the Talent; Recognize the Interest; My Dream Goals; My Future, Specify the Goals, Recognize the Personal Values; Continue Studying to the College Successfully; Join the Work World Successfully. The percentage of book feasibility results from each validator is, the media expert validator is $92,5 \%$ (very feasible), the material expert validator is $70,83 \%$ (feasible), and the user validator or the students is 86,41 (very feasible). The conclusion of this research is this book is categorized as very feasible with an average percentage of $82 \%$. It is hoped that this self-help book about career planning can be applied effectively, and also hopefully this research can be applied in other schools.
\end{abstract}

Keywords: Self-Help, Self-Help Book, Career, Career Planning, Students.

Abstrak
Penelitian ini bertujuan untuk mengembangkan sebuah produk buku bantuan
diri tentang perencanaan karir guna memberikan informasi pada siswa/i
mengenai langkah-langkah dalam merencanakan karir. Penelitian ini
menggunakan metode Penelitian dan Pengembangan (Research and
Development) yang dikembangkan oleh Borg and Gall. Penelitian yang
dilakukan tergolong dalam penelitian R\&D skala kecil (Small-Scale R\&D),
karena penelitian yang dilakukan menggunakan beberapa tahapan saja yaitu
penelitian dan pengumpulan informasi; perencanaan; pengembangan format
produk awal; validasi produk awal; dan revisi produk. Pada tahap validasi,
produk dinilai oleh tiga validator ahli yaitu validator ahli media, validator ahli
materi, serta dinilai oleh validator pengguna yaitu siswa. Penelitian ini
menghasilkan sebuah buku bantuan diri yang berjudul 'Kamu Mau Jadi


Apa?". Adapun Materi-materi yang tersedia dalam buku bantuan diri dalam perencanaan karir adalah Kenali Diri: Siapakah Saya; Cari Tahu Tentang Bakat; Mengenali Arah Minat; Cita-citaku, Masa Depanku; Tentukan Tujuan, Kenali Nilai-nilai Pribadi; Sukses Melanjutkan Studi ke Perguruan Tinggi; Sukses Memasuki Dunia Kerja. Hasil persentase kelayakan buku dari masingmasing validator yaitu validator ahli media menilai sebesar 92,5\% (sangat layak), validator ahli materi menilai sebesar 70,83\% (layak), serta validator pengguna yaitu siswa menilai sebesar $86,41 \%$ (sangat layak). Kesimpulan dari penelitian ini yaitu buku bantuan diri tentang perencanaan karir dikategorikan sangat layak dengan rata-rata persentase sebesar $82 \%$. Buku bantuan diri tentang perencanaan karir diharapkan dapat diujicobakan lebih lanjut agar dapat efektif untuk digunakan, serta penelitian ini diharapkan dapat dilakukan di sekolah lainnya.

Kata Kunci: Bantuan Diri, Buku Bantuan Diri, Karir, Perencanaan Karir, Siswa

\section{Introduction}

The adolescent phase is a transition period from childhood to adulthood. This period provides a developmental influence in emotional, social, and physical aspects ${ }^{1}$ Youth development tasks focus on preparing to carry out roles and demands in entering the adult phase which is directly related to attitudes, knowledge, and skills (actions and behavior) before entering the adult phase. Harvighurst argues that regarding career orientation, including choosing and planning for future careers is one of the tasks of adolescent development that must be completed. ${ }^{2}$

Everything that are expected of adolescents in the process of going through life must be supported by an understanding related to career skills that support them. This explanation is in line with the opinion of that adolescence begins to focus on thinking about the future. ${ }^{3}$ In the final phase of entering adolescence, the main source of thought is focused on interest in the career field.

According to Zwell, In general, the lack of knowledge in career planning can be reviewed by the lack of insightful information about the concept of self-understanding, namely cognitive abilities, special talents in academics, individual interests that are general or special, assessment of learning outcomes from all fields of study, types of

\footnotetext{
${ }^{1}$ Elizabeth B Hurlock, Psikologi Perkembangan. 5th Edition (Jakarta: Erlangga, 2002), 21.

2 Ita Juwitaningrum, "Program Bimbingan Karir untuk Meningkatkan Kematangan Karir Siswa SMK," PSIKOPEDAGOGIA Jurnal Bimbingan dan Konseling 2, no. 2 (December 1, 2013): hlm. 45, https://doi.org/10.12928/psikopedagogia.v2i2.2580.

${ }^{3}$ Hurlock, Psikologi Perkembangan. 5th Edition.
} 
personality traits, facilities supporting cognitive skills. ${ }^{4}$ The right planning and career decision lie in the ability of individuals to manage information about the concept of self-understanding and understanding of the surrounding environment. ${ }^{5}$

Marsudi argues that understanding of the situation that occurs to students must be able to be understood by counselors in schools. ${ }^{6}$ Efforts by counselors in providing guidance and counseling services in the field of career development focus on the goal of realizing career services that are following the needs of students. Duties, responsibilities, and authority possessed by counselors in providing guidance and counseling services to students that are closely related to students' self-development need to be adjusted to the needs, potential, interests, talents, and personalities of students at school. The counselor's job as a facilitator in optimizing the careers of students should also be able to provide services that help students understand and evaluate each information received, and determine and make a decision.

Based on an interview with a teacher of counselor in under graduated students at SMAN 1 Tulungagung about career understanding in students it was found that students' knowledge of career information was still very minimal. The evidence shown can be seen by student participation when career service programs conducted in schools in the form of career choice socialization from students from various universities tend to be passive. Students are still confused about interpreting career aspirations related to further studies, the concept of self-understanding (interests, talents) as well as the types and values in work. The learning methods used by counselor's teachers are still fairly classic, using lecture methods and minimal use of the media used. Counseling teachers at the school also said that they had not received special training in career guidance services. The use of media is still using PowerPoint slides and blackboards. It should be noted that this school was only established in 2013 .

The results of a preliminary study at undergraduate students on 70 students showed that: 1) students experienced confusion in determining the type of further education to be pursued $(69 \%), 2)$ do not know the prospect of a job or position if the individual completes studies (52\%), 3) inadequate career information (57\%), 4) does not know the student's self-potential $(86 \%), 5)$ depends on the economic situation of parents (47\%) and 6) almost all students stated that the best careers were Civil Servants (85\%).

\footnotetext{
${ }^{4}$ Wibowo, Manajemen Kinerja (Jakarta: PT. Raja Grafindo Persada, 2011).

${ }^{5}$ Winkel W.S and Hastuti Sri, Bimbingan Dan Konseling Di Institusi Pendidikan (Jakarta: PT. Grasindo, 2006).

${ }^{6}$ L Marsudi, Psikologi Pendidikan Dan Bimbingan (Malang: UNM Press, 2003).
} 
The development of media self-help books can be used as alternative self-help that is carried out independently to help students' career planning. Self-help book aims to guide and support the individual/client in carrying out the changes, to improve selfmanagement, not just things that are informative only. ${ }^{7}$

According to Ladd-Tucker, the benefit of self-help is a method that can change the behavior and emotions of individuals, optimize skills and change thoughts, selfconcepts, attitudes, values in themselves, motivation, and expectations. ${ }^{8}$

Research conducted by McLean and Vermeylen entitled Learning on the Margins of Adult Education: Self-help Reading about Health, Relationships, and Career Success. ${ }^{9}$ The findings that can be conveyed in the use of self-help book is the presentation of qualitative interviews with users of self-help books relating to health, relationships, and career success. Sourced from 100 adults interviewed, 96 people stated that they learned something important by reading self-help books, 75 people stated that they were able to change something about their daily lives based on the results of reading the book, and 56 people gave examples of actions concrete they do in response to suggestions made by the authors.

\section{Related Works}

\section{Self-Help}

The term self in the psychological dictionary has the meaning of self (itself) or all that is felt and believed to be true by someone about himself as an individual. Help yourself (self-help) in the opinion of Bergsma is an act of help or fix yourself without the help of others. ${ }^{10}$ Furthermore, in the context of psychology books, helping yourself is a form of solving individual personal or emotional problems without help from a professional. Based on the opinion of Kurtz, self-help can also be called a process of working for self-help that has a clear mission to help change some aspects of oneself. ${ }^{11}$

Self-help has the objective to provide the understanding and solving the problems associated with that are relevant to the individual needs of its development. The activities in support of self-help can focus on the process of self-help that has

\footnotetext{
7 C.E Watkins and R.L Campbell, Testing and Assessment in Counseling Practice (Mahwah N.J: Lawrence Erlbaum Associates, 2000).

${ }^{8}$ C.E Ladd-Tucker, "Psychological Self -Help," Mental Health Net, 2006.

9 S McLean and L Vermeylen, "Transitions and Pathways: Self-Help Reading and Informal Adult Learning," International Journal of Lifelong Education, 2014.

${ }_{10}^{10}$ A Bergsma, “Do Self - Help Books Help?," Journal of Happiness Studies 9 (2007): 341-60.

${ }^{11}$ Linda Farriz Kurtz, Self-Help and Support Groups: A Handbook for Practitioners (Sage Publication, 2007).
} 
mission obviously to help change the problematic aspects of oneself. Each individual has two roles in self-help, namely people who help and people who are helped. Activities that exist in self-help are as assistance that changes individuals in a more positive direction.

Kurtz also believes that self-help has characteristics, such as instilling hope, universality, and feelings of belonging, support, handling methods through teaching and learning, and conveying knowledge based on experience. ${ }^{12}$

The nature of self-help according to Elbraum can be achieved through several types, namely self-help groups, and self-help media such as books, websites, CDs, and DVDs. ${ }^{13}$ Self-help by Ladd-Tucker is one of the systems that have utility in the form of a method for changing behavior, methods of optimizing the skills, methods to regulate emotions, and methods to modify or to understand the concepts of self, thoughts, attitudes, values, and hope. ${ }^{14}$

\section{Self-Help Book}

According to Anderson et al revealed that the self-help book aims to guide and support the individual/client to execute the change, thus improving self-management, not just an informative thing. ${ }^{15}$ The concentration of problems that are widely discussed in self-help books targets certain disorders such as anxiety, insomnia, depression, panic attacks, and others. The format is in self-help following cognitive behavioral therapy, where respondents are supported to perform tasks between each session to deny / correct thoughts and behaviors that are individual problems.

The four pragmatic elements that show the success of self-help books according to Starker are the cost of self-help books that are cheaper than having to go to consult a therapist or a professional expert, accessibility of books that are easy to reach and use so that it can be read at lunch or night when going to sleep. ${ }^{16}$ A solution to provide individual opportunities to solve problems without having to be known by others and without having to communicate with a therapist, a self-help book is often a sale and the best purchase because reading a book like this can provide an opportunity for readers to become an important part of the book.

\footnotetext{
12 Kurtz.

${ }^{13}$ Lawrence Elbraum, Handbook Self-Help Therapies (USA: Taylor \& Francis Group, 2008).

${ }^{14}$ Ladd-Tucker, "Psychological Self -Help."

${ }^{15}$ Watkins and Campbell, Testing and Assessment in Counseling Practice.

${ }^{16}$ Bergsma, "Do Self - Help Books Help?"
} 
Bergsma divides the theme of the book into four parts, namely development, relationships, coping, and personality. ${ }^{17}$ In developing self-help books in career planning, the theme to be applied is about "personality". The background is that this theme discusses the process of knowing and understanding oneself and correcting oneself in the form of developing insights for individuals so that it is following the discussion that will be generated.

Based on the explanation from Ladd-Tucker there are ten steps needed in program self-help. In the first step, the author gives the choice to respondents to choose a self-help service program. ${ }^{18}$ The stage of choosing a self-help program is only allowed to choose 2 or 3 programs. In the second step, the writer starts to collect data according to the severity or frequency of the respondent's problem. In the third step, the writer tries to understand the problem, how to develop, the initial cause, and what causes it to continue to the respondent. In the fourth step, the writer asks respondents to be able to set realistic goals. In the fifth step, the authors ask respondents to choose a method of self-help to develop program plans. In the sixth step, the author asks respondents to understand more deeply about the detailed steps that exist in each method of self-help used and try to plan. In the seventh step, the author asks respondents to continue the whole program to assess and plot self-improvement. In the eighth step, the author and the respondent revised the agenda needed related to the business of rejection of selfchange, and continued to maintain self-motivation. In the ninth step, the authors ask respondents to plan how to maintain the progress that has been achieved. In the tenth step, the author asks the respondent to make notes about the effectiveness of the method of self-help.

Some aspects that need to be observed in making a book are about what parts are assessed or evaluated after the product has been printed. The preparation of evaluation instruments in this study was carried out according to the textbook assessment guidelines issued by the National Education Standards Agency in 2006 which were then adjusted to the characteristics of the product. ${ }^{19}$ The textbook assessment component includes four sections with the following details: (1) Feasibility of content, consisting of indicators of conformity with Competency Standards and Basic Competency in subjects, insights for progress and development, scientific substance analyzation skills,

\footnotetext{
${ }^{17}$ Bergsma.

${ }^{18}$ Ladd-Tucker, "Psychological Self -Help."

${ }^{19}$ anonim, Buletin BNSP (Jakarta: Badan Standar Nasional Pendidikan, 2007).
} 
and diversity of social values. (2) Linguistics, consisting of indicators of conformity with good and correct Indonesian language, language logic, and legibility. (3) Presentation, consisting of material, learning, and technical indicators. (4) Graphic, consisting of book size/format indicators, external design/cover, content design, quality of binding, paper quality, and print quality.

\section{Career Development Theory}

According to Super Duane Brown and Savickas Mark L, there are five stages in career development. ${ }^{20}$ These stages are the stage growth (3-13 years), the phase exploration (14-24 years), the stage establishment (25-44 years), the phase maintenance (45-64 years), and the stage disengagement (over 65 years).

Based on the developmental stages put forward by Super above, it can be concluded that high school adolescents as subjects in this study are at the tentative stage. The tentative stage concentrates on the needs, talents/abilities, interests, and values that form the basis of alternative career fields. Alternative career choices of individuals in the future depend on the extent to which adolescents can fulfill the stages of their developmental tasks.

\section{Career Planning}

Based on Corey explains that a career is all the work-life of each individual. Each career path taken by an individual may consist of one or a portion of positions which increases with the individual's work experience. ${ }^{21}$

Dillard describes career planning as an effort in the process of achieving individual career goals, which is characterized by systematic goals after completing education, planned goals related to the profession/future work, motivated in taking education, and employment/profession aspired, a realistic perspective on oneself or the environment, the ability to classify the professions of interest, respect the profession and important points in it positively, independence in the implementation of decision making, and show realistic methods of doing work which becomes an ideal. ${ }^{22}$

\footnotetext{
${ }^{20}$ Duane Brown and Savickas Mark L, Career Choice and Development Fourth Edition (San Francisco: Josey-Bass A Willy Company, 2002).

${ }^{21}$ G Corey, Groups: Process and Practice (Seventh Edition) (Belmont: Thompson Higher Education, 2006).

22 J.M Dillard, Life-Long Career Planning (Sydney: Charles E Merling Publish, 1985). 
According to Dillard explains four goals in career planning, namely improving aspects of self-understanding and self-awareness, taking personal satisfaction (personalsatisfaction), preparing yourself for appropriate and proper placement (adequate placement) in career activities, and the efficiency of time and effort carried out in career activities. $^{23}$

Based on the description described by Dillard about career planning has three aspects namely "self-knowledge, attitudes, and skills". ${ }^{24}$ The indicators of each aspect are (1) self-knowledge which includes: having goals after completing education clearly, realistic perceptions about the individual and the environment, (2) attitudes which include: clear ideals about work, encouragement to realize everything in the field of further education and work that has become an ideal, give a positive appreciation to the work and existing values, able to be independent in the stages of decision making, (3) skills that include individual skills to classify jobs that are of interest individual and display realistic efforts in achieving goals.

Dillard., explained that there are steps needed in career planning, is that individuals can recognize talent, individuals must understand interests, individuals need to understand values, individuals need to understand personalities, individuals are important to pay attention to career opportunities, individuals are important to pay attention to career appearance, and individuals are important to pay attention to lifestyle.

\section{Methods}

This subtitles describes the research methods used, starting from the type and approach of the research along with scientific reasons, data and data sources, data collection techniques, and data analysis techniques. Explanations in this section are not theoretical, but must be operational in accordance with those carried out in the study.

The research process that researchers do uses a type of Research and Development (R\&D) method. R\&D method used refers to the procedure developed by Borg and Gall. ${ }^{25}$ The purpose of this research model is to produce certain products, test the effectiveness of these products, and discover new knowledge through 'basic research' or to answer specific questions about the practical nature through 'applied research'.

\footnotetext{
${ }^{23}$ Dillard.

${ }^{24}$ Dillard.

${ }^{25}$ W.R Borg and M.D Gall, Educational Research: An Introduction, Fifth Edition (New York: Longman, 1989).
} 
This type of research using the method Research and Development (R\&D) consists of ten stages namely, research studies and field information gathering, planning, development of initial product format stages, validation of initial product stages, media product revisions, testing, operational product revisions, operational fields, final product revisions, deployments, and reports. Research carried out by researchers includes research and development (R\&D) types on a small scale (SmallScale R\&D), meaning that the stages used by researchers in this study are only a few stages.

The problem of limitations in research is Research and Development (R\&D) supported by the statement of Borg and Gall, that these limitations can be overcome by using a small-scale project model. Under Borg and Gall's statement, then in this case the researcher focused the research by providing limits only on several stages, namely from the first stage to the fifth stage. The five stages the researcher will undertake are research and information gathering, planning, developing the initial product format, validating the initial product stage, and revising the product stage.

\section{Result and Discussion}

Research and development of media products self-help books refer to the types of research and development models developed by Borg \& Gall. The research and development stage used in this study is only limited to 5 stages.

The stages consist of 1) Research and information gathering. Researchers in this stage use the questionnaire as an instrument used to obtain information related to user needs consisting of several aspects as follows: aspects of media self-help, aspects of visual elements, self-help needs, and information needed about self-help book to find out the stages of career planning. The number of respondents used as researchers as a source of information gathering related to needs analysis was 231 students consisting of 7 classes. 2) Planning, the researcher formulates an outline of the topic of the contents of the information to be reviewed and constructs into materials that will be developed in a media self-help book in career planning based on the results that have been obtained in gathering information from respondents. 3) Development of the initial product format, reference design discussion that has been carried out at the planning stage, then the researcher develops into material competencies in the form of a self-help book. Book products developed must pay attention to designs that include the type of writing used, drawings, or charts (if necessary). The size of the book that is adjusted based on 
preliminary studies is $18 \times 25 \mathrm{~cm}$, font size 12 , and with letter type century. Researchers also need to pay attention to the selection of images that match the content of the material presented, as well as the color settings in the text so that it meets the readability aspect. 4) Initial product validation, the media self-help book as a whole has been printed into a book format for product validation testing. The researcher then prepared the instrument lattice so that the validation test was conducted by 3 validators, namely the media expert validator, material expert validator, and user validator.

a) Cecep Kustandi is a lecturer majoring in Educational Technology at the Faculty of Education at the State University of Jakarta. He acted as a media expert validator to validate aspects related to the feasibility of graphics consisting of several indicators such as book size, book content design, and book cover design.

Table 1: The Validation Result of Media Expert

\begin{tabular}{|c|c|c|c|c|c|}
\hline Aspect & Indicator & Score & Total & $\mathbf{( \% )}$ & Crite ria \\
\hline \multirow{2}{*}{$\begin{array}{c}\text { Graphic Properness } \\
\text { Aspect }\end{array}$} & Book Size & 8 & & & \multirow{2}{*}{111} \\
\cline { 2 - 3 } & $\begin{array}{c}\text { Book Cover } \\
\text { Design }\end{array}$ & 46 & $92,5 \%$ & Very Proper \\
\cline { 2 - 3 } & $\begin{array}{c}\text { Book } \\
\text { Content } \\
\text { Design }\end{array}$ & 57 & & & \\
\hline
\end{tabular}

b) Dede Rahmat Hidayat is a lecturer in the Guidance and Counseling study program at the Faculty of Education at the State University of Jakarta. He acts as a material expert validator to carry out validations related to aspects of content assessment, aspects of presentation appropriateness, and aspects of career planning information services.

Table 2: The Validation Result of Material Expert.

\begin{tabular}{|c|c|c|c|c|}
\hline Aspect & Score & Total & (\%) & Criteria \\
\hline Content Assessment Aspect & 28 & & & \\
\cline { 1 - 2 } $\begin{array}{c}\text { Presentation Properness } \\
\text { Assessment Aspect }\end{array}$ & 14 & & $70,83 \%$ & Proper \\
\cline { 1 - 2 } $\begin{array}{c}\text { Career Planning Information } \\
\text { Service Aspect }\end{array}$ & 9 & & & \\
\hline
\end{tabular}

There are 15 students in class XI of SMAN 1 Tulungagung acting as user validators to validate aspects of the characteristics and benefits of self-help books in career planning. Another purpose of validation by the user is to find out the effectiveness of the book, in addition to providing ratings, suggestions, or comments. 
Table 3: The Validation Result of Students as Users.

\begin{tabular}{|c|c|c|c|c|c|c|}
\hline No. & Participant & Score & Total & Average & $(\%)$ & Crite ria \\
\hline 1. & K.N & 73 & \multirow{15}{*}{1037} & \multirow{15}{*}{69,13} & \multirow{15}{*}{$86,41 \%$} & \multirow{15}{*}{ Very Proper } \\
\hline 2. & N.F.R & 74 & & & & \\
\hline 3. & B.A & 73 & & & & \\
\hline 4. & K.L & 70 & & & & \\
\hline 5. & A.A & 78 & & & & \\
\hline 6. & C.N & 74 & & & & \\
\hline 7. & Y.S & 68 & & & & \\
\hline 8. & N.H & 65 & & & & \\
\hline 9. & R.A.C & 74 & & & & \\
\hline 10. & A.W.P & 71 & & & & \\
\hline 11. & W.A.K & 64 & & & & \\
\hline 12. & D.F & 66 & & & & \\
\hline 13. & F.A.L & 63 & & & & \\
\hline 14. & K.C.P & 64 & & & & \\
\hline 15. & D.P.A & 60 & & & & \\
\hline
\end{tabular}

c) Product Revision, the researcher has made revisions related to the results of the assessment conducted by 3 expert validators, namely media expert validator, material expert validator, and user validator. The results of the evaluation of the validators that have been revise by researchers are adding an explanation of the objectives and summaries of each material so that the feasibility of self-help media, the proportionality of the size of the pictures in the book, the addition of pictures as well as an explanation of the career planning flow, and giving color to the presentation table in the book.

\section{Conclusion}

The results of the assessment are based on research and development of media products self-help books about career planning that have been obtained from expert validators indicating the scale of criteria is worthy of further testing. The validation results obtained from the expert validators are as follows: a) the media expert validator provides an assessment with a percentage of $92.5 \%$ with a very feasible criteria scale, b) the material expert validator provides an assessment with a percentage of $70.83 \%$ with a feasible criteria scale, and c) user validators totaling 15 students gave ratings with a percentage of $86.41 \%$ with a very decent criteria scale.

The benefits of self-help books about career planning for users are (a) about career planning can contribute to students in providing information and related new insights about the stages in understanding career planning; (b) assist students in determining further studies that are under their self-concepts, talents, interests, and even 
personalities to realize future career success; (c) The rational nominal price of books is more affordable/affordable compared to having to consult with a career consulting center such as a psychologist, attending career seminars, and so on; (d) Self-help books are more practical to use wherever and whenever.

The results of research and development of media products self-help books about career planning have direct implications for high school students in obtaining information, as well as new insights in making career planning so that they can realize their ideas in the future. The media for self-help books in career planning can also be used by guidance and counseling teachers in schools as material in providing career counseling services, especially related to career planning.

Some suggestions that researchers can convey to optimize the media that have been developed, among others: (1) Teacher guidance and counseling/counselors can use selfhelp books about career planning as a reference in providing career counseling services, especially in class XI students; (2) A self-help book can be used by high school students at all grade levels, it does not even exclude the possibility that students can also use it; (3) For further researchers, they can develop media products for self-help books on career planning on a wider scale of trials so that self-help book products can be massproduced later; (4) For further researchers, they can develop media products for selfhelp books about career planning on different research subjects, so that they are not only limited to students of class XI of SMAN 1 Tulungagung; (5) For the next, researcher can perform product evaluation self-help books in career planning to make a more specific topic and multiply worksheet (work-sheet) to be given to the user.

\section{References}

Anonim. Buletin BNSP. Jakarta: Badan Standar Nasional Pendidikan, 2007.

Bergsma, A. “Do Self - Help Books Help?” Journal of Happiness Studies 9 (2007): 341-60.

Borg, W.R, and M.D Gall. Educational Research: An Introduction, Fifth Edition. New York: Longman, 1989.

Brown, Duane, and Savickas Mark L. Career Choice and Development Fourth Edition. San Francisco: Josey-Bass A Willy Company, 2002.

Corey, G. Groups: Process and Practice (Seventh Edition). Belmont: Thompson Higher Education, 2006.

Dillard, J.M. Life-Long Career Planning. Sydney: Charles E Merling Publish, 1985. 
Elbraum, Lawrence. Handbook Self - Help Therapies. USA: Taylor \& Francis Group, 2008.

Hurlock, Elizabeth B. Psikologi Perkembangan. 5th Edition. Jakarta: Erlangga, 2002.

Juwitaningrum, Ita. "Program Bimbingan Karir untuk Meningkatkan Kematangan Karir Siswa SMK." PSIKOPEDAGOGIA Jurnal Bimbingan dan Konseling 2, no. 2 (December 1, 2013): 132. https://doi.org/10.12928/psikopedagogia.v2i2.2580.

Kurtz, Linda Farriz. Self-Help and Support Groups: A Handbook for Practitioners. Sage Publication, 2007.

Ladd-Tucker, C.E. 'Psychological Self -Help.” Mental Health Net, 2006.

Marsudi, L. Psikologi Pendidikan Dan Bimbingan. Malang: UNM Press, 2003.

McLean, S, and L Vermeylen. "Transitions and Pathways: Self-Help Reading and Informal Adult Learning.” International Journal of Lifelong Education, 2014.

Watkins, C.E, and R.L Campbell. Testing and Assessment in Counseling Practice. Mahwah N.J: Lawrence Erlbaum Associates, 2000.

Wibowo. Manajemen Kinerja. Jakarta: PT. Raja Grafindo Persada, 2011.

W.S, Winkel, and Hastuti Sri. Bimbingan Dan Konseling Di Institusi Pendidikan. Jakarta: PT. Grasindo, 2006. 